\title{
No. 395
}

Shennan, I., Innes, J ., Melvin, K., Barlow, N., Watcham, E., and Davies, F., Sea Level Research Unit, Department of Geography, Durham University 2011, Preliminary investigations of the diatom stratigraphy of Borehole TA8, Portage Alaska

Received August, 2011

All data reports may be downloaded free of charge from the DGGS website. 


\section{Preliminary investigations of the diatom stratigraphy of Borehole TA8, Portage Alaska}

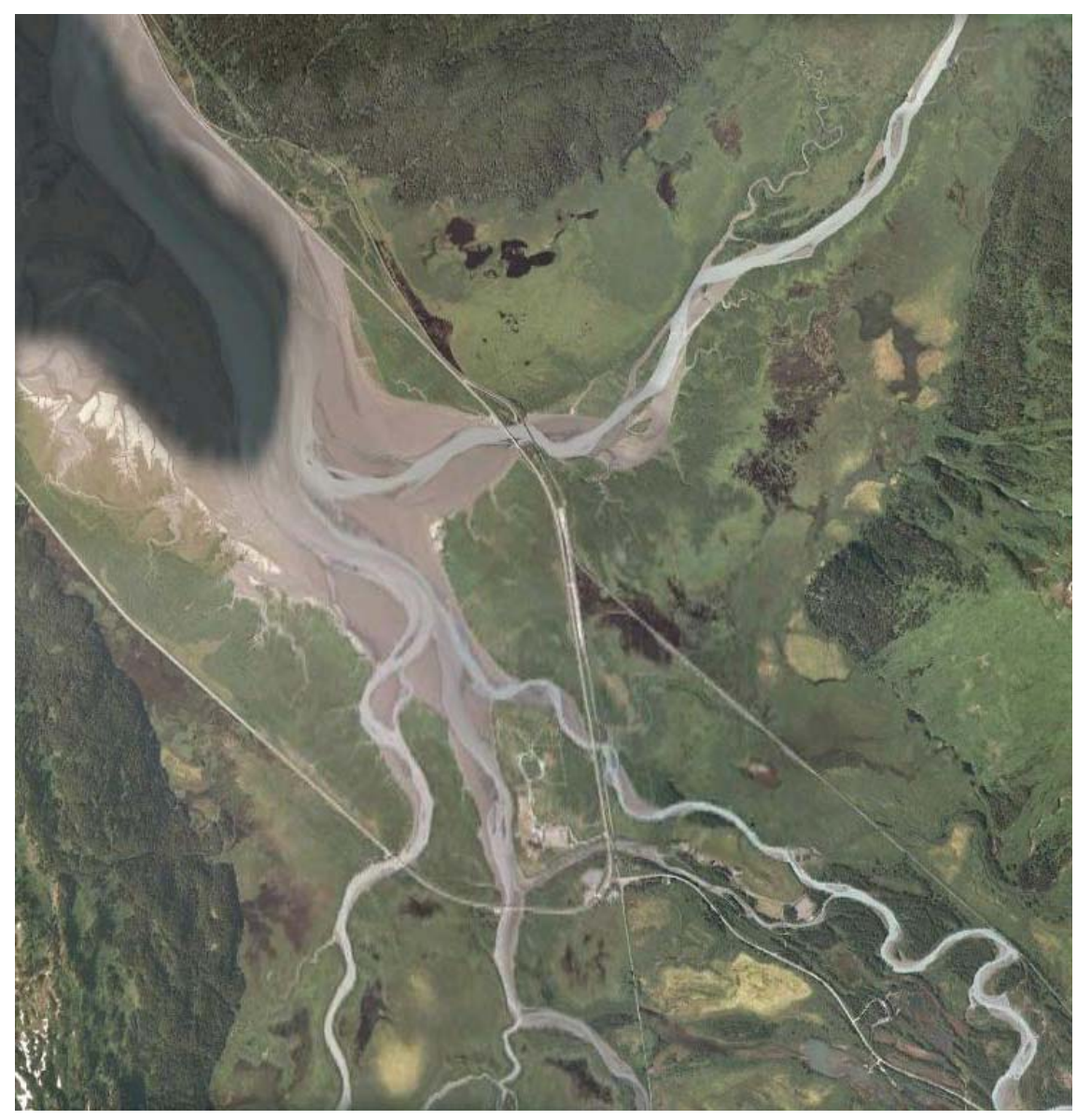

Ian Shennan, Jim Innes, Kathryn Melvin, Natasha Barlow, Emma Watcham and Frank Davies

Sea Level Research Unit

Department of Geography

Durham University

Science Laboratories

Durham DH1 3LE

UK

Corresponding author: ian.shennan@durham.ac.uk

July $18^{\text {th }}, 2011$ 


\section{Aim}

This report presents the results of diatom analyses of nine samples taken from Borehole TA8 at Portage, Alaska. Borehole TA8 was drilled in 1988, with the lithology and radiocarbon ages reported shortly afterwards (Combellick, 1991). The aim of this preliminary investigation is to ascertain the degree of preservation of fossil diatoms in Borehole TA8, using very small samples of sediment, and so inform decisions regarding the likely benefits of a comprehensive study of the whole sequence.

\section{Methods}

In order to minimise disturbance of the archived cores we sampled across two of the peat layers radiocarbon dated by Combellick (1991). First, a well developed peat with a sharp upper contact, thought to represent the penultimate great earthquake 900 years ago that produced coseismic subsidence and rapid marsh submergence. Second, a poorly defined peat layer, at a much greater depth than any cores from upper Cook Inlet previously analysed for their fossil diatom content. Appendix 1 gives the diatom counts for each of the samples and Appendix 2 shows images of some of the species identified. Appendix 3 gives the original core logs and notes on the samples taken for diatom analysis and Appendix 4 the procedures used.

\section{Interpretation}

All samples show sufficient preservation of identifiable fossil diatoms to justify further analyses. There are sufficient numbers present to give statistically reliable counts and the species are similar to those recorded in modern samples from marshes around upper Cook Inlet, suggesting that quantitative transfer function methods will have a high probability of success in providing reconstructions of relative land/sea level changes (Hamilton and Shennan, 2005).

The sharp upper contact of the peat layer dated $~ 900$ years ago has an abrupt change in diatoms across the lithologic boundary. Sample 2, at the top of but within the peat, has an assemblage dominated by freshwater and salt-intolerant species, especially Eunotia spp., whereas sample 1, from the base of the silt layer directly above has a marine and brackish assemblage, dominated by Delphineis surirella and Paralia sulcata.

The two lowest samples, 8 and 9, are above and below a poorly defined peat layer that we did not sample in order to not disturb the thin organic sediment for this preliminary investigation. Both samples 8 and 9 contain marine and brackish diatoms, along with species that suggest significant freshwater input into a tidal flat environment.

\section{Conclusions}

Fossil diatom abundances in all of the samples suggest that it will be worthwhile to analyse the complete sequence in order to correlate the record of seismic and non-seismic relative land and sea level changes in Turnagain Arm. Given that Borehole TA8 from Portage and TA1 from Girdwood (Combellick, 1991) have records that span more than 10,000 years they potentially provide a unique study as we currently have a record of earthquake cycles for only the last 4000 years (Shennan et al., 2008). 


\section{References (including those cited in Appendices)}

Combellick, R. A. (1991). Palaeoseismicity of the Cook Inlet region, Alaska: Evidence from peat stratigraphy in Turnagain and Knik Arms. Alaska Division of Geological and Geophysical Surveys Professional Report 112, 1-52.

Hamilton, S., and Shennan, I. (2005). Late Holocene relative sea-level changes and the earthquake deformation cycle around upper Cook Inlet, Alaska. Quaternary Science Reviews 24, 1479-1498.

Hartley, B., Barber, H. G., and Carter, J. R. (1996). "An atlas of British diatoms." Biopress, Bristol.

Hemphill-Haley, E. (1993). Taxonomy of recent and fossil (Holocene) diatoms (Bacillariophyta) from northern Willapa Bay, Washington. U.S. Geological Survey Open File Report 93-289, 1-151.

Palmer, A. J. M., and Abbott, W. H. (1986). Diatoms as indicators of sea-level change. In "Sea-level research: a manual for the collection and evaluation of data." (O. Van de Plassche, Ed.), pp. 457-488. Geo Books, Norwich.

Patrick, R., and Reimer, C. W. (1966). "The Diatoms of the United States. Volume 1. Monographs of The Academy of Natural Sciences of Philadelphia No 13." Academy of Natural Sciences of Philadelphia, Philadelphia.

Patrick, R., and Reimer, C. W. (1975). "The Diatoms of the United States. Volume 2, Part 1. Monographs of The Academy of Natural Sciences of Philadelphia No 13." The Academy of Natural Sciences of Philadelphia, Philadelphia.

Shennan, I., Barlow, N., and Combellick, R. (2008). Palaeoseismological records of multiple great earthquakes in south-central Alaska - a 4000 year record at Girdwood. In "Active tectonics and seismic potential of Alaska." (J. T. Freymueller, P. J. Haeussler, R. Wesson, and G. Ekstrom, Eds.), pp. 185-199. Geophysical Monograph Series, Volume 179. American Geophysical Union Washington.

Van der Werff, A., and Huls, H. (1958-1974). "Diatomeeenflora van Nederland. 8 parts." Published privately, De Hoef, The Netherlands. 


\section{Appendix 1}

Diatom counts.

See Appendix 4 for explanation and limitations of diatom classifications

Portage core samples: note depths are those measured during sampling from the archived cores July 15, 2010

\begin{tabular}{|c|c|c|c|c|c|c|c|c|c|}
\hline Core & TA8-4 & TA8-4 & TA8-4 & TA8-4 & TA8-4 & TA8-4 & TA8-4 & $\begin{array}{l}\text { TA8- } \\
12 B\end{array}$ & $\begin{array}{l}\text { TA8- } \\
12 B\end{array}$ \\
\hline Slide & 7 & 1 & 2 & 3 & 4 & 5 & 6 & 8 & 9 \\
\hline Depth (m) & 3.81 & 3.84 & 3.85 & 3.86 & 3.9 & 4.01 & 4.03 & 12.61 & 12.65 \\
\hline Depth (ft) & 12.50 & 12.60 & 12.63 & 12.66 & 12.80 & $\begin{array}{c}13.16 \\
\text { Peat }\end{array}$ & 13.22 & 41.37 & 41.50 \\
\hline Summary lithology & Silt & Silt & Peat & Peat & Peat & base & Silt & Silt & Silt \\
\hline
\end{tabular}

Marine (Polyhalobous)

\begin{tabular}{|c|c|c|c|c|c|c|c|c|c|}
\hline Actinoptychus senarius & 6 & 8 & & & & 1 & 2 & 11 & 20 \\
\hline Delphineis surirella & 107 & 110 & 6 & 2 & 54 & 7 & 11 & 115 & 98 \\
\hline Navicula pennata & 1 & & & & & & & & \\
\hline Nitzschia insignis & 1 & & & & & & & & \\
\hline Odontella aurita & & 4 & & & 1 & & 2 & & \\
\hline Paralia sulcata & 68 & & & & & & & 10 & 10 \\
\hline Rhabdonema minutum & 1 & & & & & & & & \\
\hline Surirella fastuosa & & & & & & & & 1 & 3 \\
\hline Thalassiosira eccentrica & 3 & & & & & 1 & 1 & 53 & 3 \\
\hline Triceratium favus & 1 & & & & & & & & \\
\hline
\end{tabular}

Brackish (Mesohalobous)

\begin{tabular}{|c|c|c|c|c|c|c|c|}
\hline Amphora commutata & 1 & & & & & & \\
\hline Caloneis westii & & & & & & 6 & \\
\hline Cocconeis diminuta & & 11 & 3 & & & & \\
\hline Cyclotella striata & 4 & & & & & 91 & 16 \\
\hline Diploneis smithii & & & & & & 3 & \\
\hline Navicula peregrina & 2 & 18 & & & & 12 & 6 \\
\hline Nitzschia brevissima & & & & & 1 & & \\
\hline Nitzschia obtusa & & & & 15 & 2 & 18 & 28 \\
\hline Nitzschia sigma & 15 & & & & & & \\
\hline Rhopalodia brebissonii & & & & & & & 53 \\
\hline
\end{tabular}

Fresh Brackish (Oligohalobian Halophile)

\begin{tabular}{|l|l|l|l|l|l|l|l|l|l|}
\hline Cyclotella meneghiniana & & 75 & & & 6 & 3 & 10 & 72 & 33 \\
\hline Navicula cari var. cincta & 11 & & & & & & & & \\
\hline Pinnularia aestuarii & & & & & & & 1 & & \\
\hline Pinnularia krockii & & & & 17 & 23 & 12 & 2 & 54 & 4 \\
\hline Thalassiosira fluviatilis & & & & & & & 1 & & \\
\hline
\end{tabular}

\section{Continued:}


Fresh (Oligohalobian Indifferent)

\begin{tabular}{|c|c|c|c|c|c|c|c|c|c|}
\hline Caloneis bacillum & 1 & & & & & & & & \\
\hline Cymbella minuta & & & & & & 9 & 39 & 7 & \\
\hline Cymbella sinuata & & & & & & & 3 & & \\
\hline Epithemia zebra & 1 & 1 & & & & & & & \\
\hline Eunotia flexuosa & & & 13 & 4 & 4 & & & & \\
\hline Eunotia pectinalis & 1 & & & & & & & & \\
\hline Eunotia perpusilla & & 1 & & & & & & & \\
\hline Eunotia repens & & & & & & 5 & & & \\
\hline Eunotia valida & & & 14 & 22 & & & & & \\
\hline Eunotia ventricosa & & & 2 & & & & & & \\
\hline Gomphonema gracile & & & & & & & 4 & & \\
\hline Gomphonema ventricosum & 1 & & & & & & & & \\
\hline Navicula brockmanii & 1 & & & & & & & & \\
\hline Navicula capitata & & & 2 & & & & & & \\
\hline Navicula menda & & 2 & & & & & & & \\
\hline Navicula tripunctata & 1 & & & & & & & & \\
\hline Navicula variostriata & & & & 2 & 1 & & 4 & 1 & \\
\hline Neidium clavum & & & & & & 12 & 5 & & \\
\hline Nitzschia fruticosa & & & & & 1 & 12 & 19 & 8 & 3 \\
\hline Nitzschia linearis & & & & & & & & 5 & \\
\hline Nitzschia paleacea & 10 & & & & & & & 3 & 43 \\
\hline Pinnularia angusta & & & & & & 2 & & & \\
\hline Pinnularia borealis & 1 & & & & & & & & \\
\hline Pinnularia brevicostata & & & 2 & 1 & & 12 & 12 & & 6 \\
\hline Pinnularia mesolepta & & & & & & & 2 & & \\
\hline Pinnularia microstauron & & & & & & 8 & 26 & 3 & \\
\hline Pinnularia sublanceolata & & & & & & & 1 & & \\
\hline Pinnularia sudetica & 1 & & & & & & & & \\
\hline Pinnularia viridis & & & & & & 16 & 35 & 42 & \\
\hline Stauroneis anceps & & & & & & & & 4 & \\
\hline Staurosira elliptica & 1 & & & & & & & 48 & 23 \\
\hline Staurosirella pinnata & 8 & & & & & & & 2 & \\
\hline
\end{tabular}

Fresh (Oligohalobian halophobe)

\begin{tabular}{|c|c|c|c|c|c|c|c|c|c|}
\hline Cyclotella antiqua & & & & & & & & 3 & \\
\hline Eunotia arcus & & 1 & 104 & 136 & 36 & 64 & 16 & 2 & \\
\hline Eunotia exigua & & & & & 86 & & & & \\
\hline Eunotia praerupta & & & 60 & 55 & 40 & 13 & 9 & & \\
\hline Frustulia rhomboides & 1 & & & & & & & & \\
\hline Pinnularia subcapitata & & 6 & & & 1 & 43 & 16 & & \\
\hline Staurosirella leptostauron & 2 & & & & & & 1 & & \\
\hline Tabellaria flocculosa & & & & & & 11 & 9 & & 1 \\
\hline Tabellaria fenestrata & & 5 & & 9 & & 2 & 32 & & 1 \\
\hline
\end{tabular}

Unknown

Pinnularia quadratarea? 


\section{Appendix 2}

Images of selected diatom species found in Borehole TA8. Actual images from either TA8 or other samples from Alaska boreholes.

\section{Achnanthes delicatula}
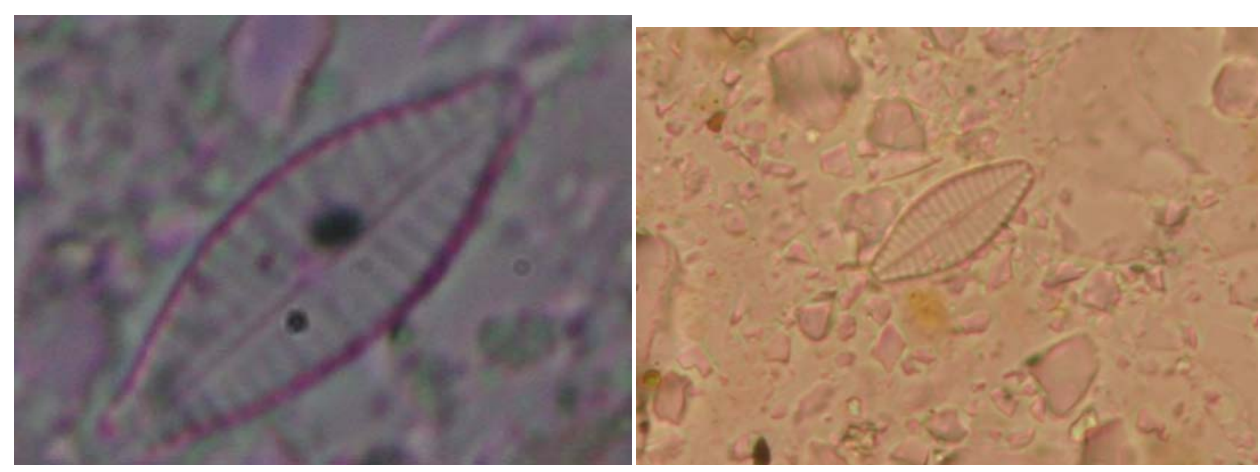

\section{Actinoptychus senarius}

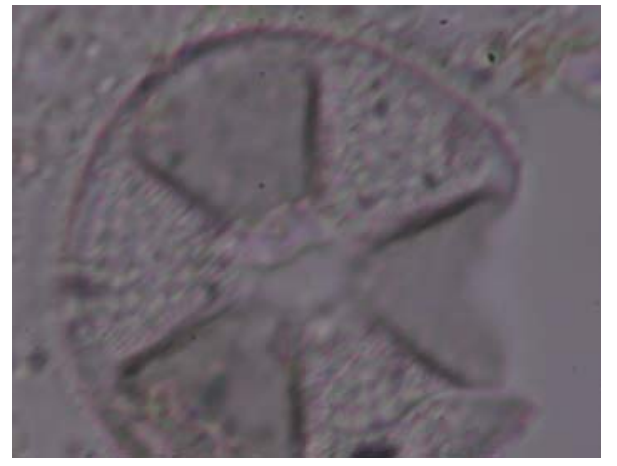

Cyclotella striata

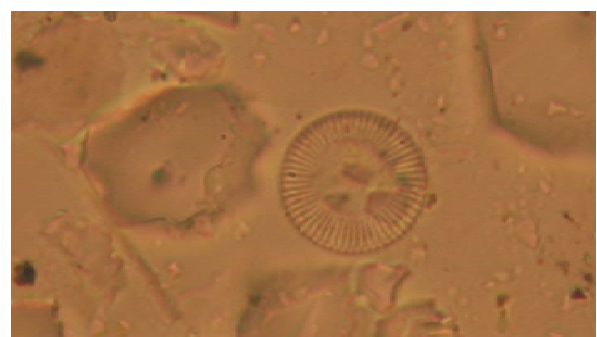

Delphineis surirella
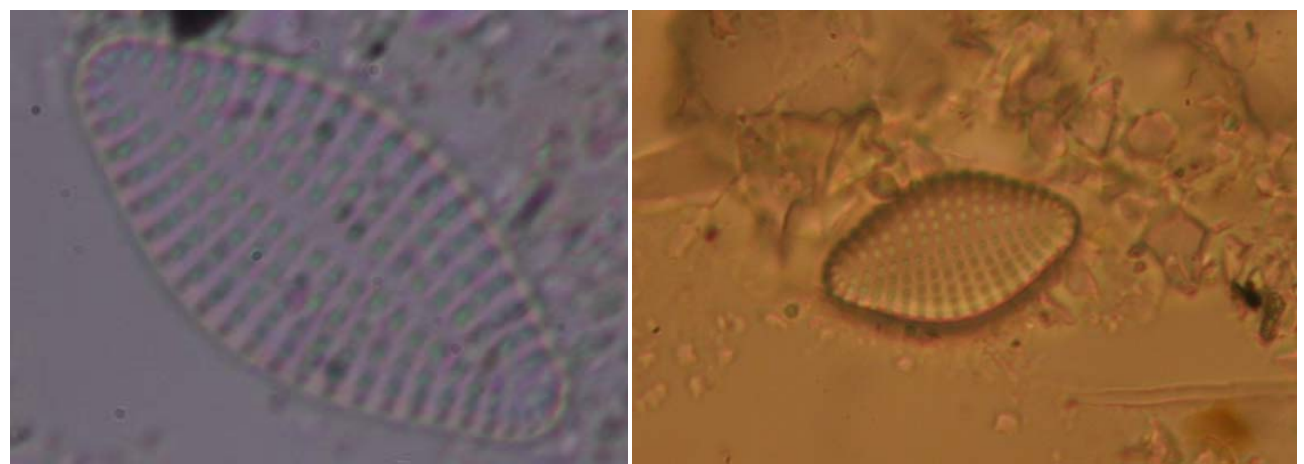
Eunotia arcus (left) \& E. exigua
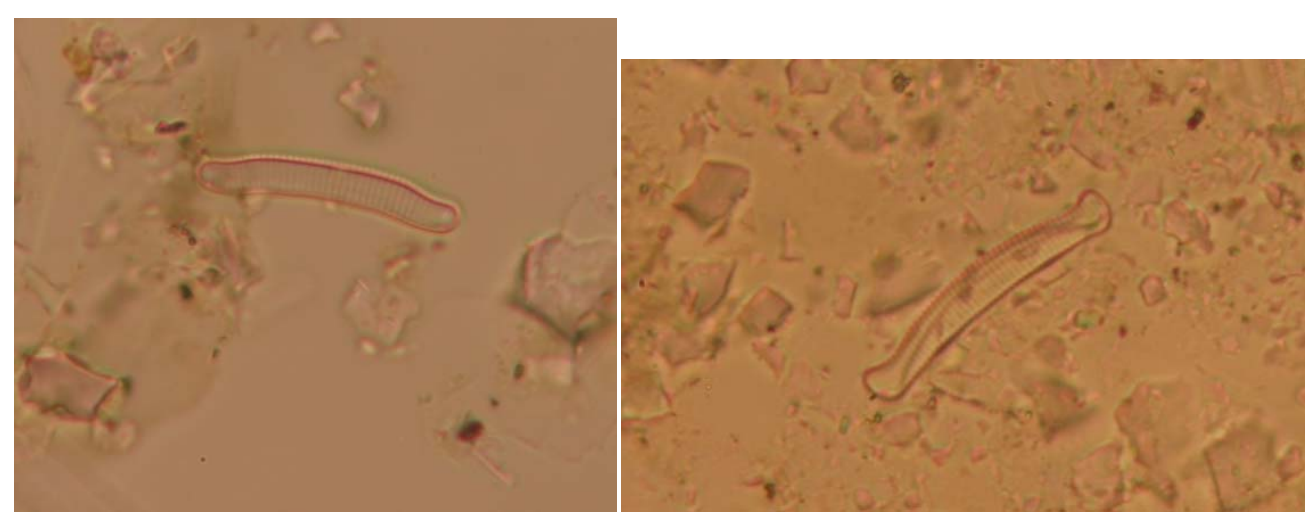

\section{Eunotia lunaris}

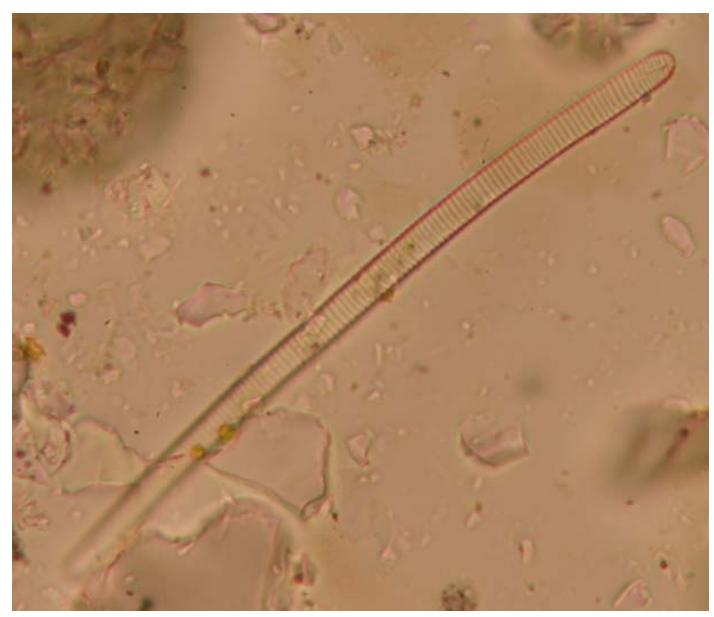

\section{Nitzschia fruticosa}

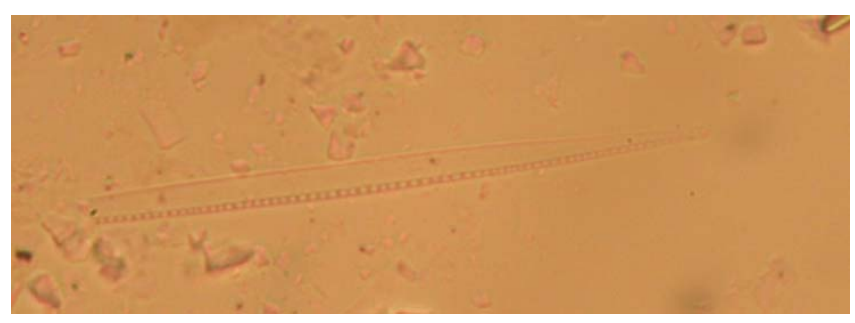

\section{Paralia sulcata}

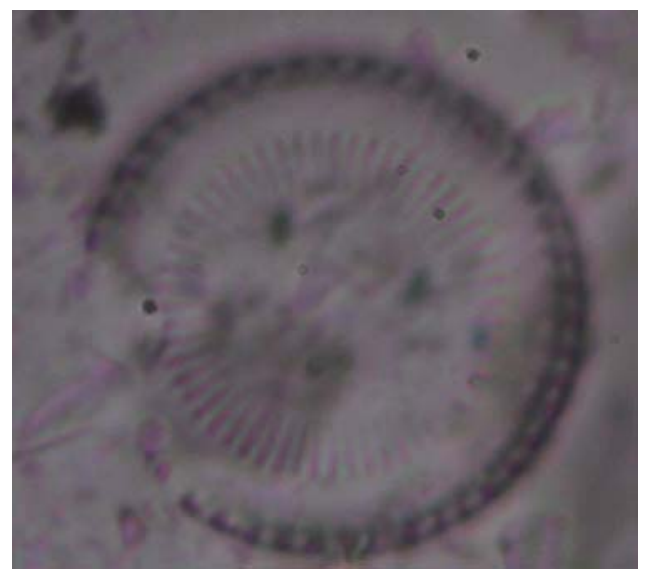




\section{Pinnularia subcapitata}

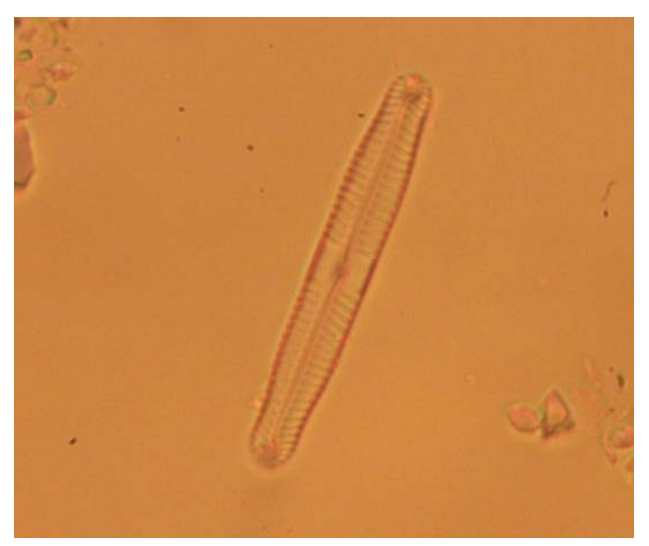

Pinnularia viridis

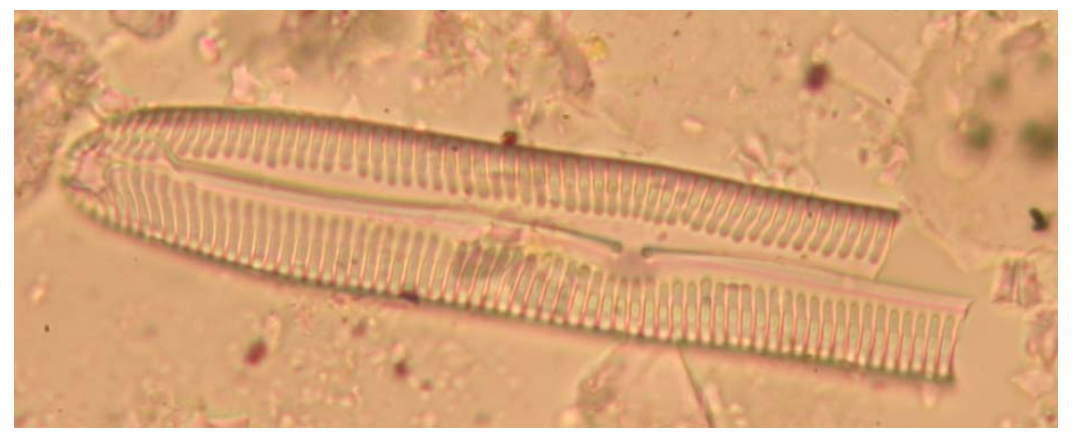

Tabellaria fenestrata (left) and T. Flocculosa

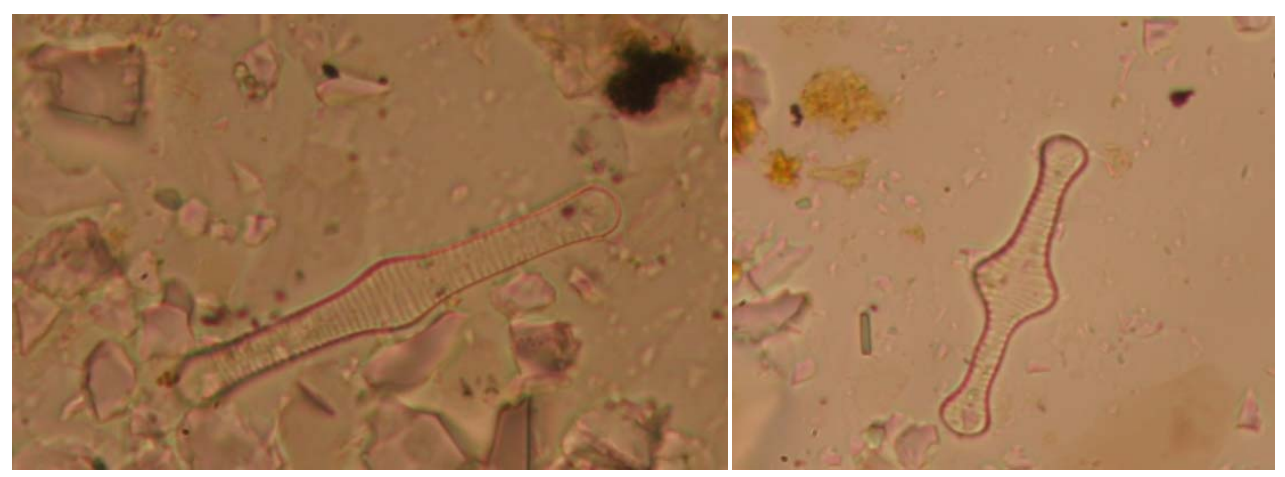

Thalassiosira eccentrica

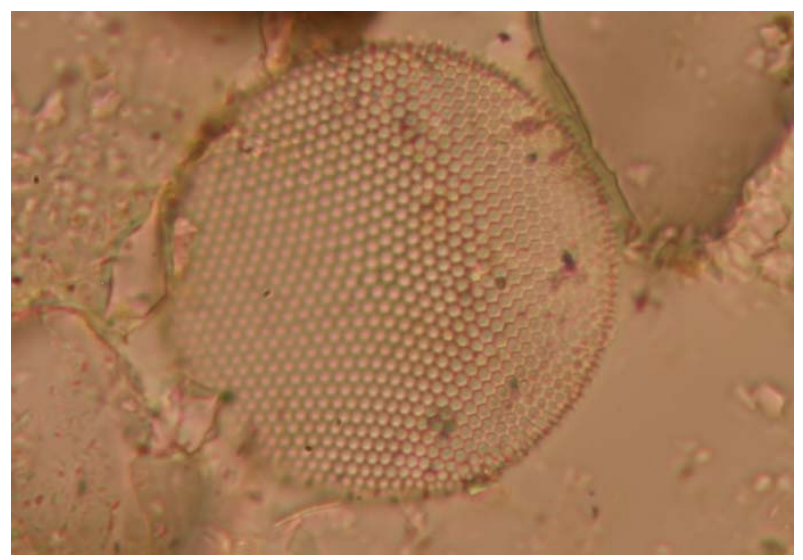




\section{Appendix 3}

Original core logs, from Combellick (1991)

TA8-4

$11.0-11.85$

$11.85-12.6$

$12.6-13.25$

$13.25-13.4$
Gray silt, silty fine sand, and clean finc sand in contorted zones; probably disturbed during sampling. Some evidence of lamination at i1.4. Negligible organics. Minor iron staining-

Gray to brownish gray clayey silt and fine sandy silt. Disseminaled organics 12.1 12.3. Scattered redge blades.

Spl TA8-4-12.5 at 12.4-12.6 (GS).

Brown to dark brown sedge and woody peat. Increasing silt toward base. Sharp upper contact.

Spl TAB-4-12.7 at 12.6-12.75 (C14).

Brownish gray organic-rich silt.

Radiocarbon sample GAX-15218: $885 \pm 120$ BP

TA8-12B

$41.0-41.4$

41.4-41.55

$41.55-43.5$
Gray laminated silt and silty fine sand. No visible organics.

Gray to brownish gray silt with thin layers of organic material. Possibly a buricd peat layer.

Sol TA8-12B-4I.5 at $41.4-41.55$ (C) 4$)$

Gray to brownish gray silt with scattered organics and very faint laminations in lower $1.0 \mathrm{n}$. No distinct upper contact. Distorted organic zone (sedge?) at 42.3.

Radiocarbon sample GAX-15223: 4150 \pm 130 BP

Note: the depths above are in feet, those reported in Appendix 1 are in meters, and are the depths measured during sampling on July 15, 2010. There may be slight differences to the depths of boundaries due to the core drying out during storage.

Samples taken, July 2010

$\begin{array}{lccccccccc} & & & & & & & \text { TA8- } & \text { TA8- } \\ \text { Core } & \text { TA8-4 } & \text { TA8-4 } & \text { TA8-4 } & \text { TA8-4 } & \text { TA8-4 } & \text { TA8-4 } & \text { TA8-4 } & \text { 12B } & 12 B \\ \text { Slide } & 7 & 1 & 2 & 3 & 4 & 5 & 6 & 8 & 9 \\ \text { Depth }(\mathrm{m}) & 3.81 & 3.84 & 3.85 & 3.86 & 3.9 & 4.01 & 4.03 & 12.61 & 12.65 \\ \text { Depth }(\mathrm{ft}) & 12.50 & 12.60 & 12.63 & 12.66 & 12.80 & 13.16 & 13.22 & 41.37 & 41.50 \\ & & & & & & \text { Peat } & & \text { Silt } & \text { Silt } \\ \text { Summary lithology } & \text { Silt } & \text { Silt } & \text { Peat } & \text { Peat } & \text { Peat } & \text { base } & \text { Silt }\end{array}$




\section{Appendix 4:}

Diatom methods

Preparation of diatom samples followed standard laboratory methods (Palmer and Abbott, 1986) with a minimum count of 250 diatom valves possible for most samples. With only very small amounts of sediment taken from the archive cores we could not experiment with different densities of residue on the slides, therefore we have found it better to use, where appropriate, photographs taken from other cores in Alaska that we have studied.

The two key reference volumes for coastal and estuarine diatoms are based on NW European material (Hartley et al., 1996; Van der Werff and Huls, 1958-1974) together with supplementary information from the Pacific Northwest (Hemphill-Haley, 1993) and flora of north American freshwater species (Patrick and Reimer, 1966; Patrick and Reimer, 1975).

In broad terms, the order of diatom salinity classes (Appendix 1) should reflect change from tidal flat through tidal marsh, to freshwater marsh and bog. Marine (polyhalobous) and brackish (mesohalobous) groups usually dominate tidal flat environments and freshwater groups tolerant of different degrees of salinity (oligohalobous-halophile and oligohalobous-indifferent) become dominant through the transition from tidal marsh to freshwater marsh. Salt-intolerant species (halophobous) characterise the most landward communities, including those from acidic bogs above the level of highest tides.

The summary salinity classes were originally defined in the studies in NW Europe. Samples from upper Cook Inlet show that the environmental tolerances of a number of species are much broader. For example Navicula cari var cincta,Tabellaria fenestrata and T.flocculosa are classified within different freshwater groups (Appendix 1 ) yet we have found them across tidal marshes and tidal flat locations around upper Cook Inlet (Hamilton and Shennan, 2005). 